\title{
Morphological characterization, distribution and ecology of four species of Amanita from north-western Himalaya, India
}

\author{
Mehmood T, Bhatt RP and Singh U
}

Department of Botany \& Microbiology, H.N.B. Garhwal University, Srinagar, Garhwal - 246174, Uttarakhand, India,

Mehmood T, Bhatt RP, Singh U 2019 - Morphological characterization, distribution and ecology of four species of Amanita from north-western Himalaya, India. Asian Journal of Mycology 2(1), 222-234, Doi 10.5943/ajom/2/1/13

\begin{abstract}
Four species of Amanita namely; A. concentrica, A. flavipes, A. fritillaria and A. avellaneosquamosa are described from North-western Himalaya, India. Morphological details and illustrations are given here.
\end{abstract}

Key words - Amanitaceae - Jammu and Kashmir - taxonomy - Uttarakhand

\section{Introduction}

Amanita is a large genus in the family Amanitaceae, which has 1007 listed species in amanitaceae.org (Tulloss \& Yang 2018) and about 62 species are reported from India (Tibpromma et al. 2017, Bhatt et al. 2017, Das et al. 2017, Hosen et al. 2018, Mehmood et al. 2018 a, b, c, d). The genus was introduced by Persoon (1797). Since then many mycologists (Roze 1876, Earle 1909, Gilbert 1940, Corner \& Bas 1962, Singer 1951, Yang 1997, Cui et al. 2018) have worked on the taxonomy and systematics of this group and split it into smaller genera. Presently, the family Amanitaceae consists of five genera i.e., Amanita, Catatrama, Limacella, Limacellopsis and Myxoderma (Cui et al. 2018). During macrofungal forays in north-west Himalaya, the first author collected several specimens of Amanita in coniferous and broad-leaved forests. In this paper, we described four species of Amanita which were poorly known from India. These species are described here with macro and microscopic details. The study also examines the mycorrhizal host(s) and the range of distribution for these species (Table 1).

\section{Materials and Methods}

\section{Morphological observations}

Macromorphological characteristics were documented in the forest or base camp from fresh and dissected young to mature basidiomata. Photography was accomplished using a digital camera (Sony cyber-shot W730 and Cannon Power Shot SX 50). Colour codes follow Kornerup \& Wanscher (1978). Samples were dried using an electric drier. Micromorphological characteristics were observed with a compound microscope (Olympus CH20i) with dried material mounted in 5\% $\mathrm{KOH}, 1 \%$ Phloxin, Melzer's reagent and 1\% Congo red. To present basidiospore measurements, the following notation was used: " $[n / m / p]$ " indicating $n$ basidiospores were measured from $m$ basidiomata of $p$ collections with a minimum of 20 basidiospores from each collection. Biometric 
variables followed those in Tulloss \& Lindgren 2005, Hosen et al. 2018). Drawings of microscopic features were made freehand.

\section{Results}

Amanita concentrica T. Oda, C. Tanaka \& Tsuda, Mycoscience 43 (1): 81 (2002) Figs 1, 2 Basidiomata medium to large sized. Pileus $70-118 \mathrm{~mm}$ wide, initially hemispherical then convex to plane at maturity, white to yellowish white (3A1-2) centre, cream to pale yellow (4A3) toward margin, viscid when moist, shining; context 4-7 mm thick, thinning slowly toward margin, white, turning pinkish slowly; margin short striated, striation up to $15 \mathrm{~mm}$ long, appendiculate, decurved to incurved, slightly uplifted with age. Universal veil on pileus covered with white (1A1) or yellowish white to cream colour, pyramidal or sub-pyramidal to conic warts, 3-4 mm wide, often discolouring to yellowish brown towards tips of warts. Lamellae free, crowded, 5-9 mm broad, white to yellowish white (3A1-2). Lamellulae truncate to subtruncate, of 3-6 lengths. Stipe 100-135 × 13-18 mm, tapering upward, white to pale yellow (1A2-3A2), squamulose to scaly, light yellow (3A2) at apex, decorated with yellowish brown conical warts at base; context white, stuffed to solid, reddish on handling. Bulb 41-58 $\times$ 23-38 mm, white, subclavate to ventricose or napiform, white to yellowish white (3A2). Universal veil on stipe base covered with 3-6 concentric rings of warts, white, turning grayish yellow to brownish orange (6B3-6D4). Partial veil superior, membranous, white, friable. Odour indistinct. Taste not recorded. Spore print white.

Basidiospores (8-) 9-10.5 (-11.5) × (6.3-) 7-8 (-8.5) $\mu \mathrm{m}, \quad \mathrm{L}=9.5 \mu \mathrm{m} ; \mathrm{W}=7.5 \mu \mathrm{m} ; \mathrm{Q}=$ (1.19-)1.22-1.33(-1.46); $\mathbf{Q}=1.29$, hyaline, thin walled, smooth, inamyloid, broadly ellipsoid to ellipsoid, apiculus sublateral, up to $1 \mu \mathrm{m}$ long; contents monoguttulate. Basidia (45-)53-58(-66) $\times$ (10.5-)11.5-12(-13) $\mu \mathrm{m}$, thin-walled, 2-4-spored, sterigmata up to 2-4 $\mu \mathrm{m}$ long, clamp connections absent. Lamellar edge cells sterile, with inflated cells clavate or pyriform 21-42 × 10-14 $\mu \mathrm{m}$, colourless, frequent to abundant. Subhymenium $w_{s t}$-near $=30-50 \mu \mathrm{m} ; w_{s t}$ far $=48-76 \mu \mathrm{m}$, basidia arising from subglobose to broadly ellipsoid cells 11-18 × 8-16 $\mu \mathrm{m}$. Hymenophoral trama bilateral, divergent; $w_{s c}=35-70 \mu \mathrm{m}$, filamentous, undifferentiated hyphae 3-7 $\mu \mathrm{m}$ wide, thin-walled, hyaline; inflated cell up to $65 \times 27 \mu \mathrm{m}$; clamp connections often observed. Pileipellis 150-195 $\mu \mathrm{m}$ thick, filamentous, undifferentiated hyphae $2-5 \mu \mathrm{m}$ wide, thin-walled, hyaline. Pileus context filamentous, undifferentiated hyphae 4-9 $\mu$ m wide, thin-walled, branched, hyaline, ellipsoid cells up to $85 \times 17$ $\mu \mathrm{m}$, thin-walled, hyaline; vascular hyphae up to 6-11 $\mu \mathrm{m}$ wide. Universal veil on pileus filamentous, undifferentiated hyphae 3-8 $\mu \mathrm{m}$ wide; inflated cells clavate to broadly clavate $31-57$ $\times 12-23 \mu \mathrm{m}$, subglobose to ovoid 23-57 × 19-49 $\mu \mathrm{m}$. Partial veil filamentous, undifferentiated hyphae dominant, 3-8 $\mu \mathrm{m}$ wide, aseptate and branched, with a cluster of inflated cells, narrow ellipsoid to elongated $109-156 \times 14-17$ subclavate cells up to $38 \times 16 \mu \mathrm{m}$. Stipe context longitudinally acrophysalidic; acrophysalidic 85-218 × 12-28; filamentous, undifferentiated hyphae 5-10 $\mu$ m wide. Clamp connections absent in all tissue.

Habit and habitat - Solitary to scattered on the ground in a mixed forest of Quercus leucotricophora, Myrica esculenta.

Specimens examined - Uttarakhand, Pauri, Pedhkhal, 19 July 2013, TM/RPB 13-0019; Pedhkhal, 24 July 2013, TM/RPB 13-0036; Pauri town, 27 July 2013, TM/RPB, 13-0048; Khirsu, 01 August 2014, TM/RPB 14-0265; Rudraprayag, Jakhdhar, 06 August 2015 TM/RPB, 15-0885; Adwani, 28 August 2015 TM/RPB 15-0995; Adwani, 03 September 2016 TM/RPB 16-1426; Nanital, Mukteshwar, 17 August 2016 TM/RPB, 16-1314. Jammu \& Kashmir, Rajouri, Dodaaj 18 July 2018, TM, 18-1601.

Notes - Amanita concentrica belongs to Amanita [sect. Amanita, series Amanita] stirps Concentrica (Tulloss \& Yang 2018).

In the field, Amanita concentrica is morphologically characterized by white to yellowish white pileus covered with the whitish pyramidal warts turning brownish with age, a bulbous stipe base covered with concentric rows of warts on the upper part of bulb and broadly ellipsoid to ellipsoid basidiospores. Morphologically Amanita concentrica is very similar A. eijii Z.L. Yang 
based on concentric rows of warts on the upper part of bulb. But A. eijii is members of Amanita [sect. Lepidella] subsect. Solitariae. However, the inamyloid basidiospores place A. concentrica into subgenus Amanita.
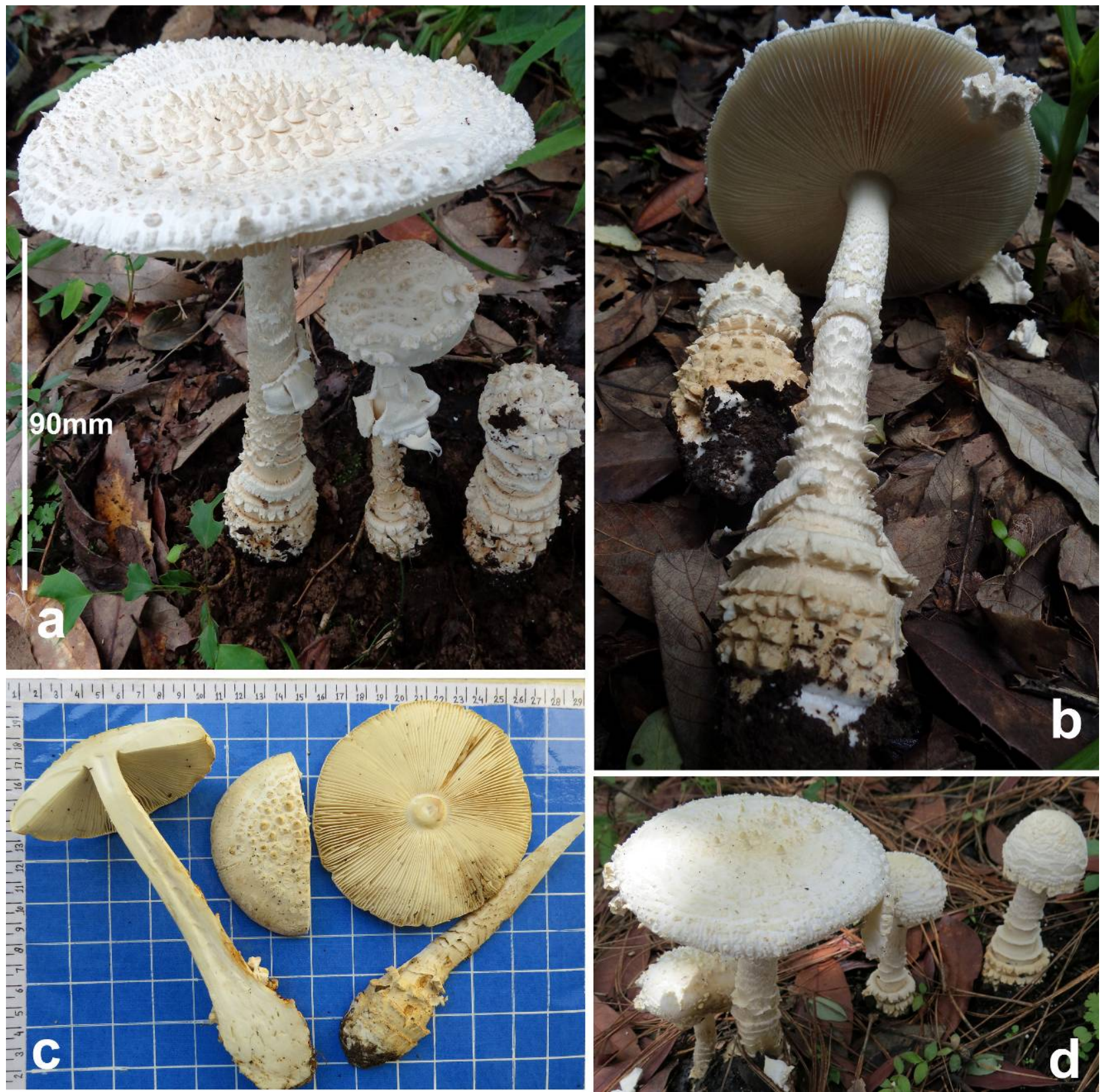

Fig. 1 - Amanita concentrica. a, b, c \& d. Basidiomata in habitat and the base camp.

Amanita flavipes S. Imai, Bot. Mag. (Tokyo), XLVII, 428, (1933)

Figs 3, 4

Basidiomata small to medium sized. Pileus 30-70 mm wide, convex, then plano-convex, slightly depressed at the centre; dull yellow to grayesh yellow (3B4-8) or yellowish orange, dry, sometimes slightly viscid when moist, shiny, smooth, glabrous; margin non-striate, nonappendiculate; context 2-3 mm thick, thinning evenly toward margin, unchanging when cut or bruised. Universal veil on pileus as pale yellow (3A3) pastel yellow (3A4) or olive yellow (3C6-7) floccose to sub-felted patches. Lamellae 3-4 mm broad, free to nearly adnate, close to crowded when mature (6-9 lamellae/10 mm) at the margin, white to yellowish white (1A2). Lamellulae attenuate, of several lengths. Stipe 60-110 × 8-10 mm, tapering upward, stuffed, dull yellow to greyish yellow (3A3-4) background decorated with yellowish coloured squamules. Partial veil membranous, superior, dull yellow (3A3), edges slightly striated, persistent. Bulb ovate to napiform 
15-29 × 13-25 mm, pulverulent, surrounded at the base of stipe, apricot-yellow, empire-yellow or light cadomium, friable, fugacious; spores white in mass, ovate to napiform 15-29 × 13-25 mm, white to dirty white (1A1-2). Universal veil as dark grey (1F1) warts. Odour indistinct. Taste not recorded. Spore print white.

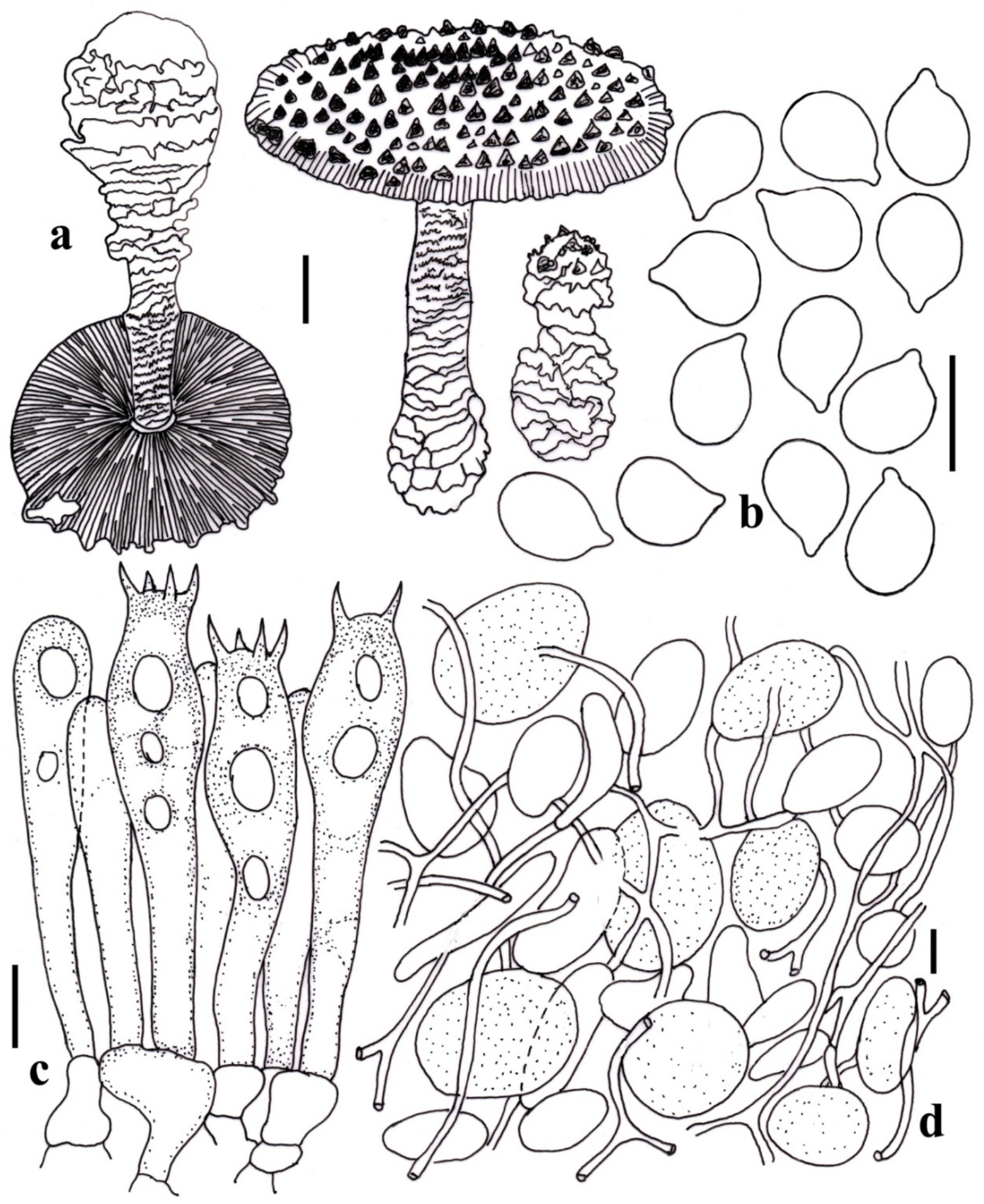

Fig. 2 - Amanita concentrica. a Basidiomata. b Basidiospores. c Basidia. d Elements of universal veil on pileus surface. Scale bars: $a=10 \mathrm{~mm}, \mathrm{~b}-\mathrm{d}=10 \mu \mathrm{m}$. 

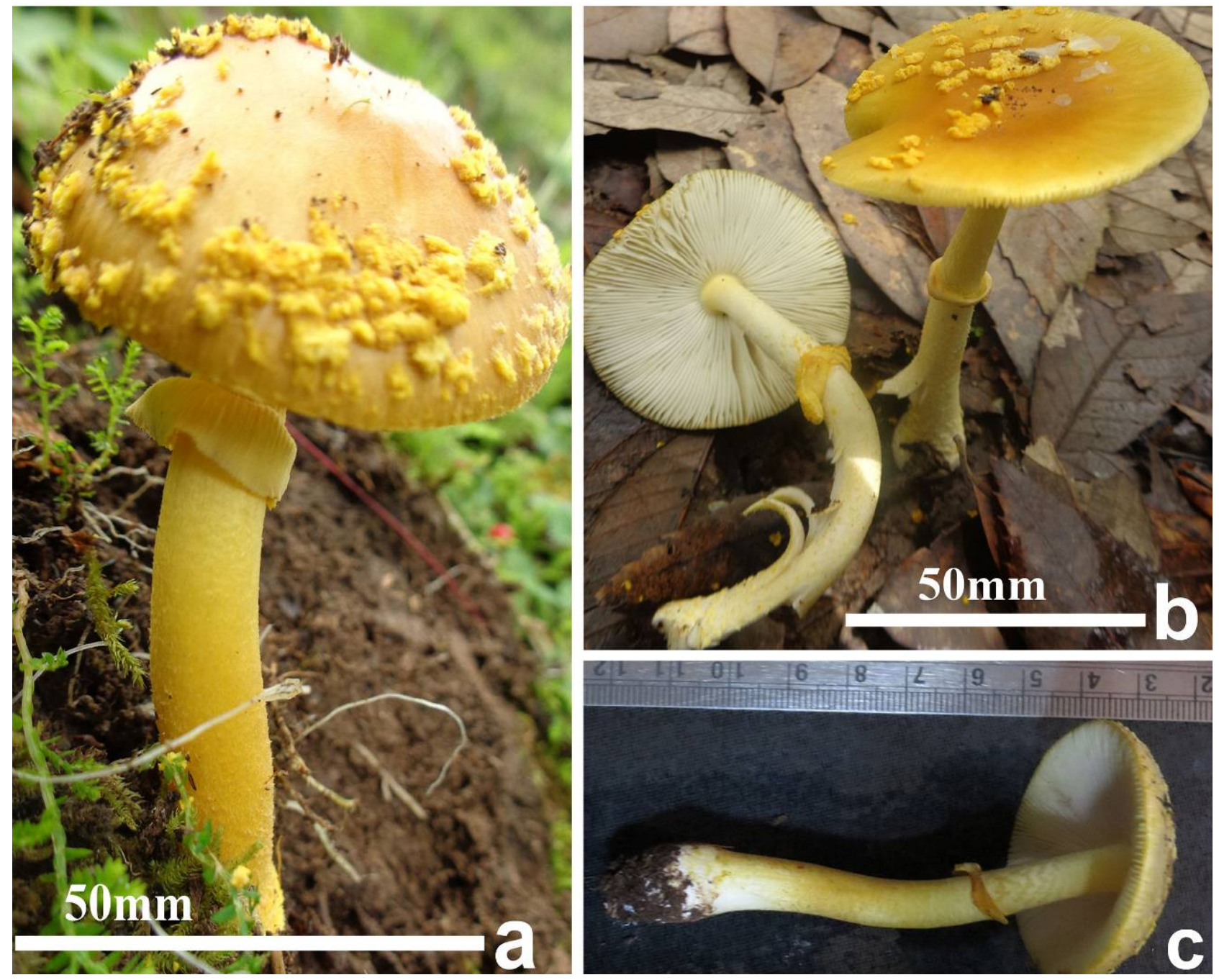

Fig. 3 - Amanita flavipes. a-c Basidiomata in its natural habitat and base camp.

Basidiospores (6.3-) 6.5-9.5 (-11) $\times(4.8-)$ 5-7 (-8.5) $\mu \mathrm{m}, \mathrm{L}=8.0 \mu \mathrm{m} . \mathrm{W}=5.8 \mu \mathrm{m} ; \mathrm{Q}=$ (1.20-)1.25-1.42 (-1.55); $\mathbf{Q}=1.34$, colorless, smooth, hyaline, thin-walled, amyloid, broadly ellipsoid to ellipsoid, sometimes subglobose or elongate, apiculus, sublateral, cylindric; contents mono- to multiguttulate. Basidia (26-)32-38(-42) $\times(8.5-)$ 9.0-10.5(-12.0) $\mu \mathrm{m}$, narrowly clavate to clavate, with sterigmata up to $5 \mu \mathrm{m}$ long. Clamp connection absent at the base of basidia. Lamellar edge cells sterile, filamentous undifferentiated hyphae 3-5 $\mu \mathrm{m}$ wide, hyaline, thin-walled; inflated cells dominating, mostly globose to subglobose 10-24 × 11-20 $\mu \mathrm{m}$, colourless, thin-walled. Subhymenium $w_{s t}$-near $=28-44 \mu \mathrm{m} ; w_{s t}$ far $=37-58 \mu \mathrm{m}$ wide, basidia arise from subglobose to ovoid cells 12-18 × 8-14 $\mu \mathrm{m}$. Hymenophoral trama bilateral, divergent $w_{s c}=30-52 \mu \mathrm{m}$, filamentous undifferentiated hyphae 4-6 $\mu \mathrm{m}$ wide. Pileipellis up to $100 \mu \mathrm{m}$ thick, slightly gelatinized at the surface, mostly ungelatinized, with yellow to brownish yellow vascular pigmentation, filamentous, undifferentiated hyphae up to 3-6 $\mu \mathrm{m}$ wide, thin-walled. Universal veilon pileus filamentous undifferentiated hyphae, 3-8 $\mu \mathrm{m}$ wide, branching, with inflated cells; subglobose to broadly ellipsoid cell up to 20-40 $\times 15-30 \mu \mathrm{m}$. Universal veil on stipe base filamentous undifferentiated hyphae 3-9 $\mu \mathrm{m}$ wide, more abundant than on pileus, branching, hyaline, inflated cells like those on pileus surface; vascular hyphae 8-11 $\mu \mathrm{m}$ wide. Stipe trama longitudinally acrophysalidic; filamentous, undifferentiated hyphae 3-7 $\mu \mathrm{m}$ wide; acrophysalides cells 120-280 × 20-40 $\mu \mathrm{m}$. Partial veil filamentous, undifferentiated hyphae 3-6 $\mu \mathrm{m}$ wide, branching, hyaline, inflated cells, thin-walled, clavate to subclavate, 130-185 $\times 22-38 \mu \mathrm{m}$, occasionally with intracellular pale brown pigment. 

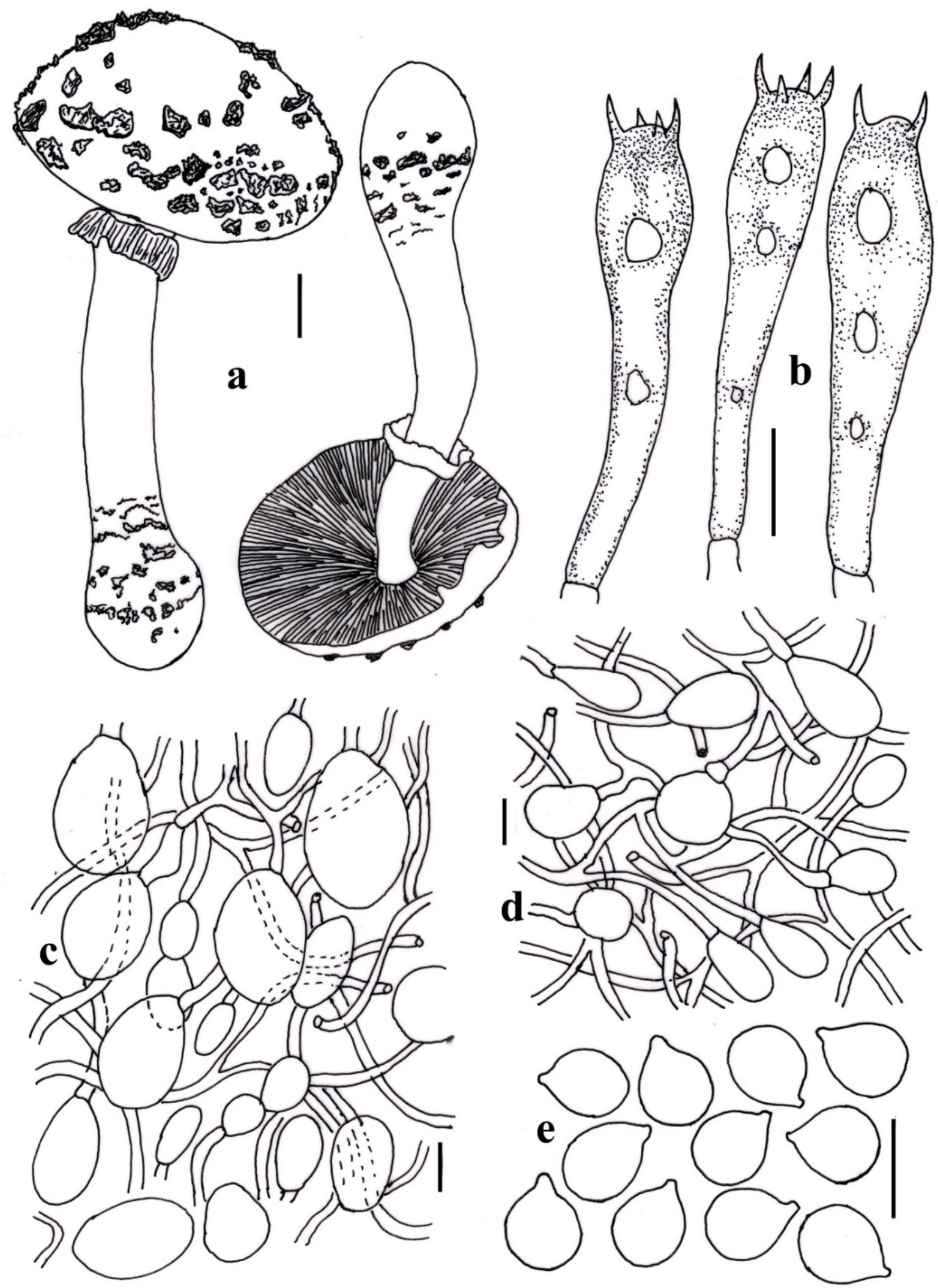

Fig. 4 - Amanita flavipes. a Basidiomata. b Basidia at different stages of development. c Elements of universal veil pileus. d element of partial veil. e Basidiospores. Scale bars: $a=10 \mathrm{~mm}, \mathrm{~b}-\mathrm{d}=10$ $\mu \mathrm{m}$.

Habit and habitat - Solitary to scattered in temperate mixed forest dominated by Quercus floribunda, Q. semecarpifolia, Q. dilitata and Abies pindrow at the higher elevation above $2500 \mathrm{~m}$ and with $Q$. leucotrichophora and Rhododendron arboreum, at lower altitude at $1900 \mathrm{~m}$. 
Specimens examined - Uttarakhand, Rudraparyag, Chopta-Baniyakund, 30 July 2015, TM/RPB, 15-761; Chopta-Baniyakund, 31 July 2015 TM/RPB15-772;Chopta-Baniyakund, 01 August 2015 TM/RPB, 15-800; Pauri, Phedkhal, 12 August 2015 TM/RPB 15-903; ChoptaBaniyakund 10 August 2014 TM/RPB; Chamoli, 23 August 2015 TM/RPB, 15-948; ChoptaBaniyakund, 22 July 2015 TM/RPB, 16-1138; Chopta-Baniyakund, 25 July 2015 TM/RPB, 161209; Chopta-Baniyakund, 24 August 2016 TM/RPB, 16-1340; Chopta-Baniyakund, 03 August 2017 TM/RPB, 17-1536. Jammu \& Kashmir, 13 August 2018.

Notes - Amanita flavipes is characterized by its dull yellow to grayesh yellow or yellowish orange coloured pileus covered with pale yellow pastel yellow or olive yellow floccose to sub-felted patches universal veil remnants on pileus, broadly ellipsoid to ellipsoid basidiospores.

In the field Amanita flavipes is somewhat similar to some yellow coloured species such as Amanitaelongate Peck, Amanita flavoconia var. flavoconia, A. franchetii (Boud.) Fayod. A. elongata. However, Amanita flavoconia var. flavoconia (originally described from the USA) differ by their deep orange-yellow coloured pileus. Moreover A. elongata has ellipsoid basidiospores (7.5-10.5 × 5.0-6.9) $\mu \mathrm{m}$ (Jenkins 1982). Amanita franchetii differs by its citrine yellow to yellow pileus, universal veil from two to three incomplete rings of warts at the top of the bulb (Neville \& Poumarat 2004). Morphologically as well as microscopically the Indian material matches well with original description (Imai 1933).

Amanita fritillaria (Berk.) Sacc., Sylloge Fungorum 9: 2 (1891)

Figs 5, 6

Basidiomata medium-sized. Pileus $60-100 \mathrm{~mm}$ wide, hemispherical at first, then convex to plane, brownish grey (5D2) or greyish brown (5D3) to sepia (5F4), slate grey (3F2) slightly darker over centre, slightly uplifted with age, dry, shiny. Margin non-striate, non-appendiculate. Pileus context 3-5 mm thick, thinning evenly toward margin, unchanging when cut or bruised. Universal veil on pileus as grey (3C1-E1) to dark grey (1F1) felted to sub-felted easily removable patches. Lamellae 4-5 mm broad, free to nearly adanate, with decurrent lines on the stipes, crowded when mature, white. Lamellulae attenuate, of several lengths. Stipe 80-140 × 10-15 mm, tapering upward, stuffed, white background decorated with greyish brown (5D3) to chocolate brown (6F5) fibrils, turning slightly darker when bruised. Partial veil apical to subapical, membranous, skirt-like, brownish grey (5D2) covered with very small greyish warts on edges. Bulb ovate to napiform 15-29 $\times 13-25 \mathrm{~mm}$, white to dirty white (1A1-2). Universal veil as dark grey (1F1) warts. Odour indistinct. Taste not recorded. Spore print white.

Basidiospores (6.5-) 7.0-9.2 (-9.8) $\times(4.8-)$ 5.2-6.8 (-7.2) $\mu \mathrm{m}, \mathrm{L}=8.3 \mu \mathrm{m} ; \mathrm{W}=6.6 \mu \mathrm{m} ; \mathrm{Q}=$ (1.10-)1.15-1.32 (-1.35); $\mathbf{Q}=1.28$, smooth, hyaline, colorless, thin-walled, amyloid, subglobose to broadly ellipsoid, apiculus, lateral to sublateral, monoguttulate. Basidia (36-)37-45(-52) × (8.5-) 9.2-10(-10.5) $\mu \mathrm{m}$, narrowly clavate to clavate, mostly 4-, occasionally 2-spored, with sterigmata up to $5 \mu \mathrm{m}$ long. Clamp connection absent at the base of basidia. Lamellar edge cells sterile, filamentous, undifferentiated hyphae 3-5 $\mu \mathrm{m}$ wide, hyaline, thin-walled; inflated cells dominating, mostly globose to subglobose 11-23 $\times 11-18 \mu \mathrm{m}$, colorless, thin-walled. Subhymenium $w_{s t}-n e a r=$ 19-42 $\mu \mathrm{m}$ thick, $w_{s t}$-far $=34-50 \mu \mathrm{m}$; inflated cells, in 3-4 layers, subglobose, ovoid, 10-20 × 8-12 $\mu \mathrm{m}$. Hymenophoral trama, bilateral, divergent $w_{c s}=28-42 \mu \mathrm{m}$; filamentous, undifferentiated hyphae 2-8 $\mu \mathrm{m}$ wide, branching, hyaline. Pileipellis up to $120 \mu \mathrm{m}$ thick, filamentous, undifferentiated hyphae up to 4-8 $\mu \mathrm{m}$ wide, thin-walled. Universal veil on pileus filamentous, undifferentiated hyphae, 2-6 $\mathrm{m}$ wide, branching, with inflated cells; globose to subglobose to narrowly clavate $26-48 \times 10-24 \mu \mathrm{m}$. Universal veil on stipe base similar to that of pileus. Partial veil filamentous, undifferentiated hyphae 2-5 $\mu \mathrm{m}$ wide, branching, hyaline, inflated cells terminal, thin-walled, clavate to subclavate, 110-115 × 20-36 $\mu \mathrm{m}$. Stipe trama longitudinally acrophysalidic; acrophysalides $120-310 \times 25-45 \mu \mathrm{m}$; filamentous, undifferentiated hyphae $2-8 \mu \mathrm{m}$ wide, thinwalled, hyaline.

Habit and Habitat - Solitary, scattered in temperate mixed forest dominated by Quercus leucotrichophora and Cupressus torulosa.

Specimens examined - Uttarakhand, Pauri, Pedhkhal, 16 July 2015, TM/RPB 15-658; 
Rudraprayag, Chopta, 18 July 2015, TM/RPB 15-684; Chopta-Banyakund, 05 July 2015, TM/RPB 15-847; Chopta-Banyakund, 18 July 2015, TM/RPB 15-990. Chopta-Banyakund, 31 July 2015, TM/RPB 15-1024; Jakhdhar, 13 September 2015, TM/RPB 15-1063. Nainital, Mukteshwar 16 August 2016, TM/RPB15-1315.
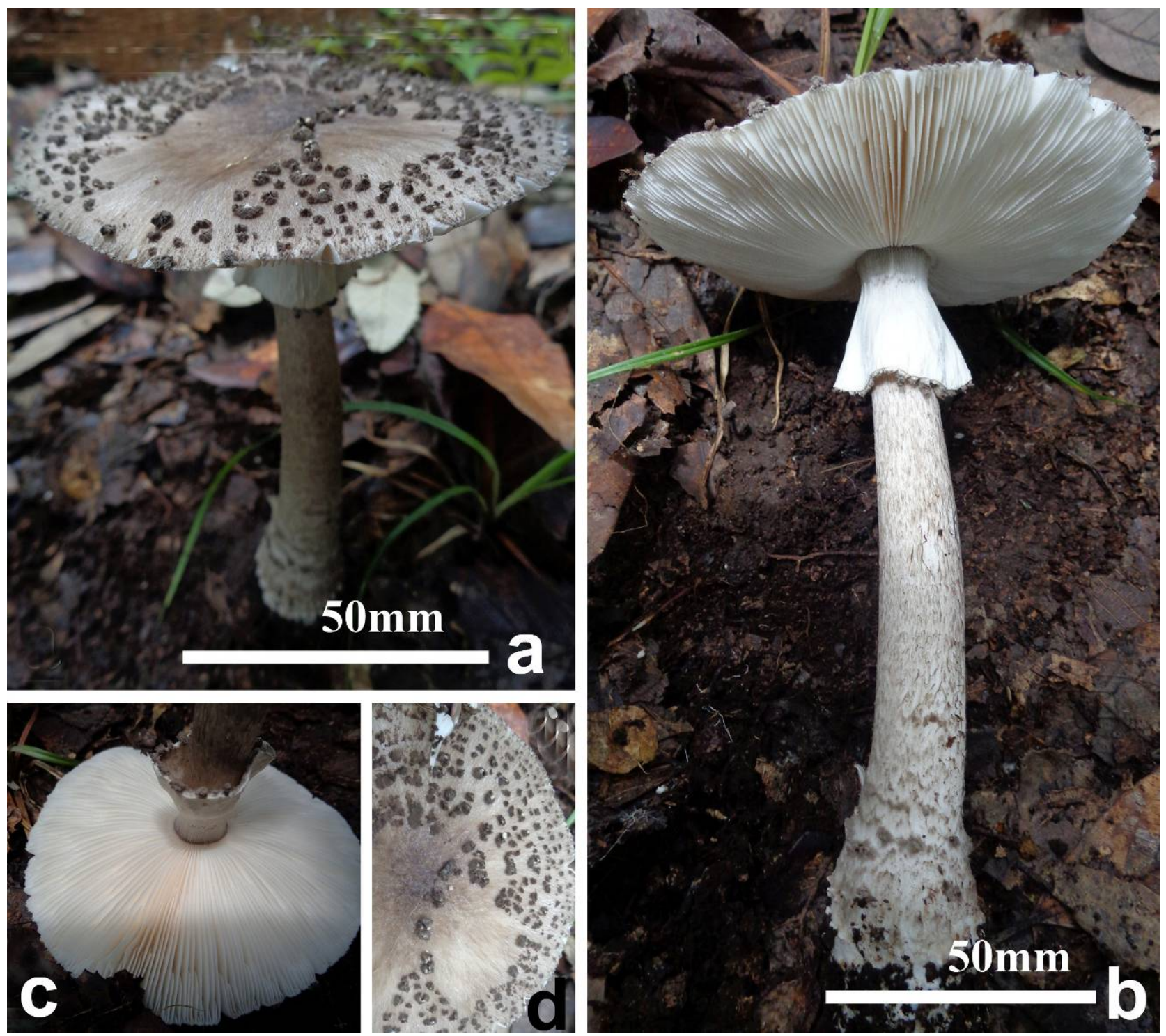

Fig. 5 - Amanita fritillaria. a-d Basidiomata in its natural habitat.

Notes - Amanita fritillaria, belongs to [subgenus Lepidella], section Validae, which is characterized by amyloid spores, non-appendiculate pileus margin and non-membranous universal veil (Corner \& Bas 1962, Bas 1969).

In the field, Amanita fritillaria is characterized by its medium-sized fruiting body with a brownish grey to greyish brown pileus covered with grey to dark grey universal veil, subglobose to broadly ellipsoid basidiospores, and the absence of clamps.

Species in section Validae having greyish brown to brownish grey pileus exhibiting some morphological similarities to Amanita fritillaria are A. spissacca Imai from Japan and A. tristis from Singapore

Amanita spissacca differ from A. fritillaria by its more floccose stipes and flat and large patches of universal veil on the pileus. Moreover, the universal veil remnants on the stipe base of Amanita spissacca are powdery (Imai 1933). Amanita tristis has dark fuscous-grey pileus covered with conical to wart-like universal veil remnants on pileus and context turning slight pale 
ochraceous-buff on cutting or bruising (Corner \& Bas 1962). Amanita pilosella can be easily distinguished from Amanita sepiacea by its greyish brown pileus covered with innate dark fibrillose streaks, globose to broadly ellipsoid $(7-10 \times 5.5-8 \mu \mathrm{m})$.

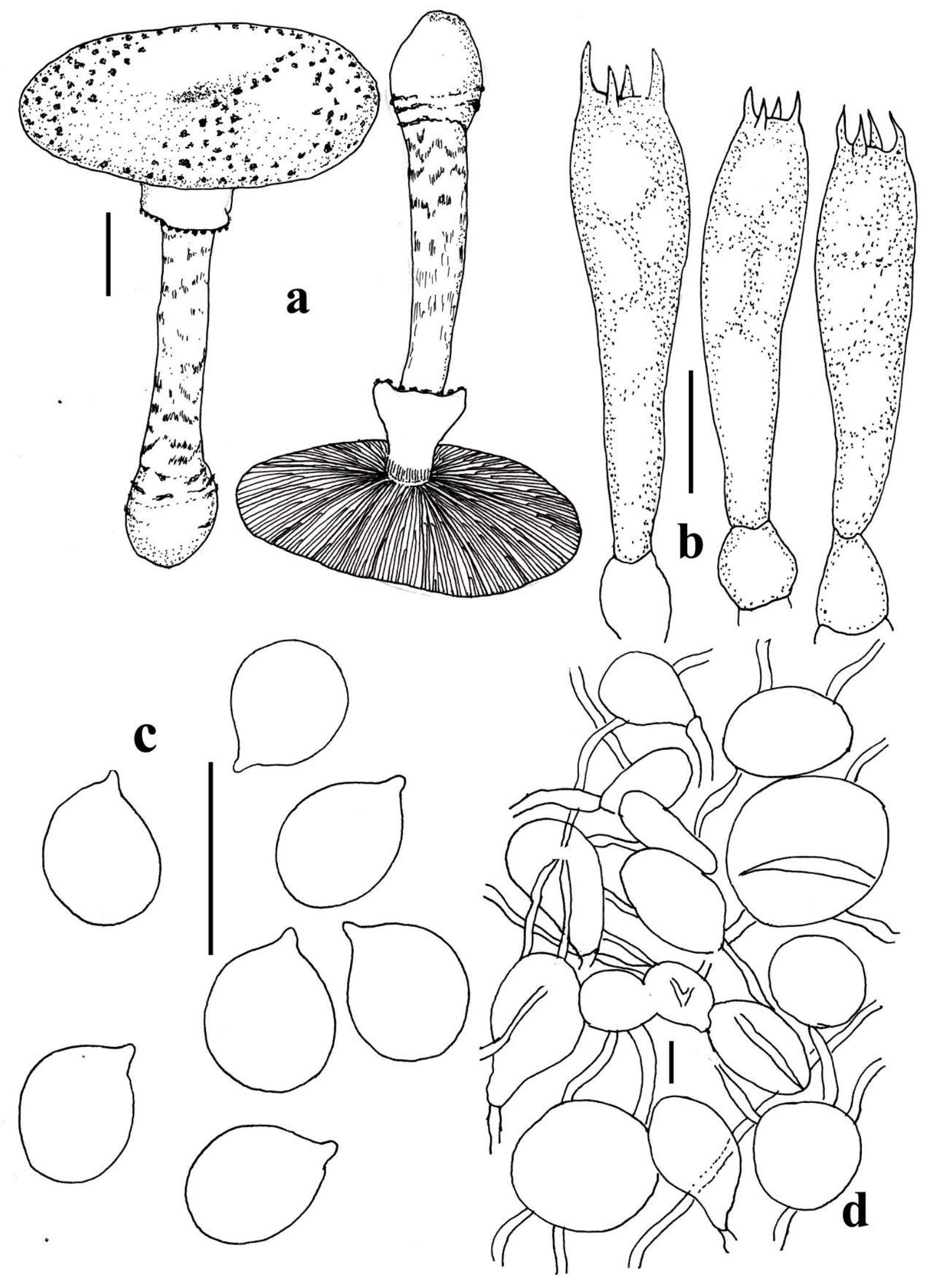

Fig. 6 - Amanita fritillaria. a Basidiomata. b Basidia at different stages of development. c Basidiospores. d Elements of universal veil pileus. Scale bars: $a=10 \mathrm{~mm}, \mathrm{~b}-\mathrm{d}=10 \mu \mathrm{m}$. 
Basidioma medium sized. Pileus 50-90 mm wide, initially hemispherical then convex to plano-convex, surface dry, white (2A1) to cream colour, dry, shining; context 2-4 mm thick, white, thinning evenly toward margin; marginslightly striated, striation up to $11-15 \mathrm{~mm}$, appendiculate. Universal veil on pileus reddish blond (5C4) to brownish orange (6C7-8) coloured, easily separable scales densely covered at the centre, diminishing in size toward margin. Lamellae free crowded (810 lamellae/10mm) white to cream-coloured, turning yellowish with age, edge slightly wavy. Lamellulae attenuate of 3-4 lengths, common. Stipe 9-14 × 8-18 mm, thick, equal or slightly tapering upward, scaly, white, covered by powdery scales. Stipe context white, unchanging when cut or bruised, hollow or stuffed. Partial veil fragile and easily broken. Universal veil 35-49 × 31$39 \mathrm{~mm}$, saccate, membranous, with a free limb 20-38 mm high. Outer surface dirty white (2A1) to dull-pinkish and inner surface is white (1A1). Odour indistinct. Taste not recorded. Spore print white.
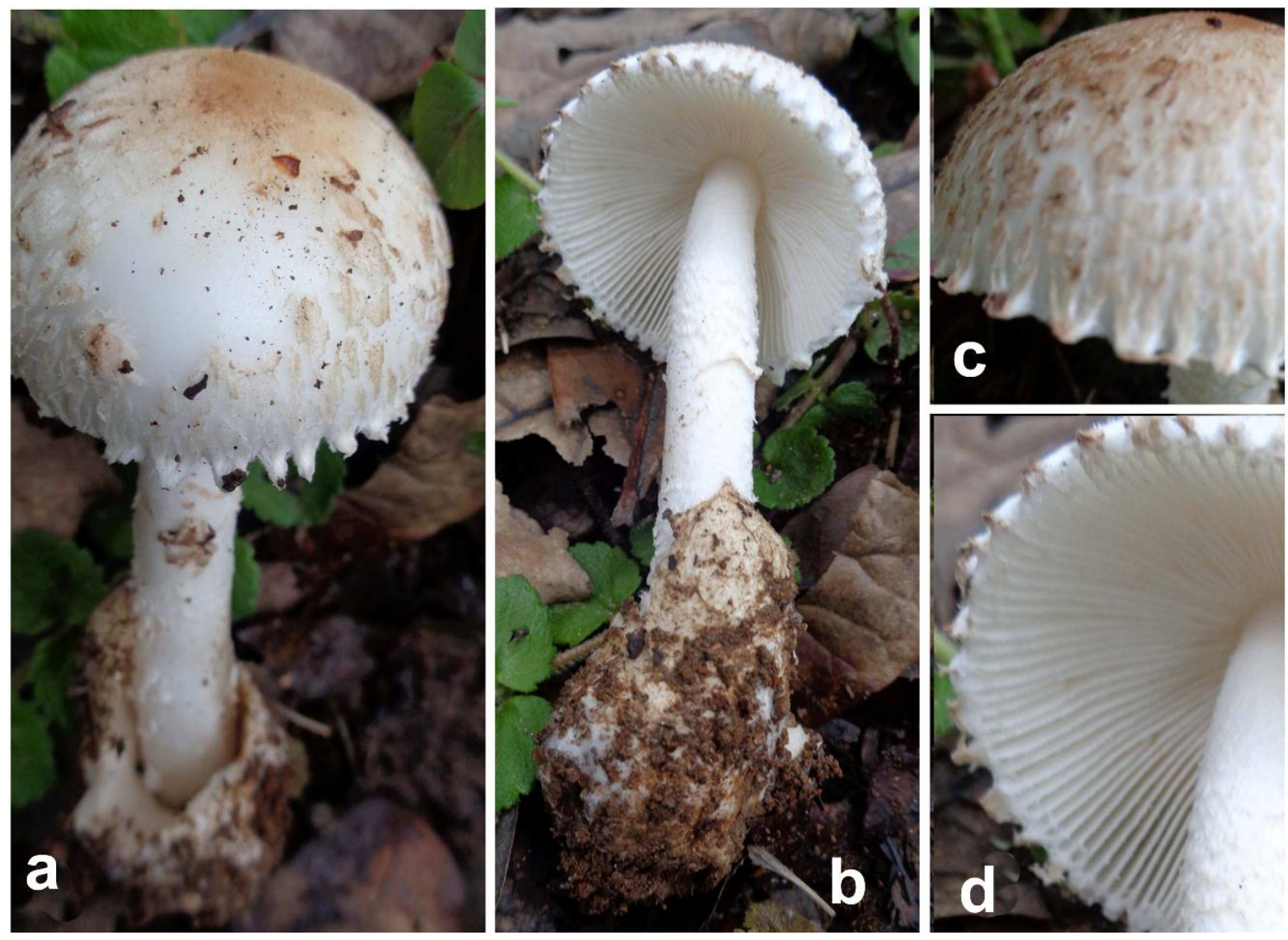

Fig. 7 - Amanita avellaneosquamosa. a-b Fresh basidioma in the field. c universal veil remnants on pileus. d lamellae.

Basidiospores (9.0-) 10-12(-14) $\times(5.5-)$ 6.0- 7.5(-8.5) $\mu \mathrm{m} ; \mathrm{L}=11 \mu \mathrm{m} ; \mathrm{W}=6.5 \mu \mathrm{m} ; \mathrm{Q}=$ (1.55-) 1.62-1.75(-1.84); $\mathbf{Q}=1.69$, elongate, sometimes ellipsoid, amyloid, colorless, hyaline, thin-walled, smooth. Lamellae edge sterile with inflated cells pyriform or clavate, 10-30 × 9-16 $\mu \mathrm{m}$, colourless, frequent. Subhymenium $w_{s t}$-near $=50-105 \mu \mathrm{m}$ thick, $w_{s t}-$ far $=110-145 \mu \mathrm{m}$, basidia arising from inflated cells (up to $15 \times 10 \mu \mathrm{m}$ wide. Hymenophoral trama bilateral, divergent $\mathbf{w}_{c s}=$ 40-80 $\mu \mathrm{m}$; inflated cells ellipsoidal to cylindrical cells $20-120 \times 12-28 \mu \mathrm{m}$, filamentous, undifferentiated hyphae 4-17 $\mu \mathrm{m}$ wide; vascular hyphae 8-12 $\mu \mathrm{m}$ wide. Pileipellis 110-165 $\mu \mathrm{m}$ thick, two-layered; upper layer 40-60 $\mu \mathrm{m}$ thick, gelatinized, radially arranged 5-10 $\mu \mathrm{m}$ wide, filamentous, undifferentiated hyphae with yellowish vacuolar pigments; lower layer 70-95 $\mu \mathrm{m}$ thick, non- gelatinized, filamentous, undifferentiated hyphae 4-12 $\mu \mathrm{m}$ wide, compactly arranged, colorless, thin-walled, hyaline. Universal veil on pileus with element irregularly 
arranged;filamentous undifferentiated hyphae up to 4-12 $\mu \mathrm{m}$ wide, thin-walled, colorless, hyaline; inflated cells subglobose to ellipsoid 30-110 × 12-30 $\mu \mathrm{m}$, hyaline, thin-walled.

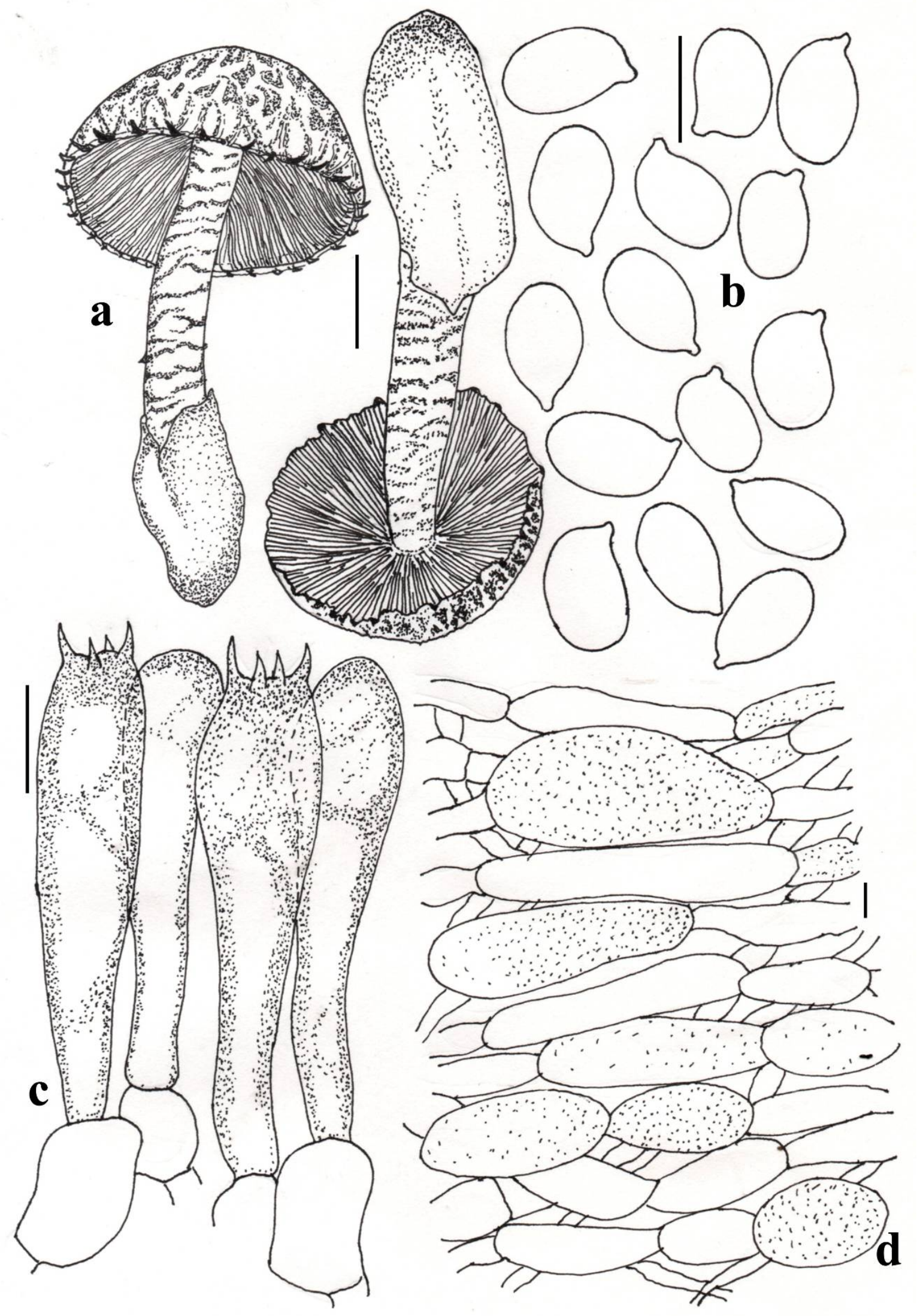

Fig. 8 - Amanita avellaneosquamosa. a basidiomata. b Basidiospores. c subhymenium cells and basidia. $d$ universal veil remnants on pileus. Scale bars: $a=10 \mathrm{~mm}$; $\mathrm{b}-\mathrm{d}=10 \mu \mathrm{m}$. 
Universal veil on stipe base with element irregularly arranged; filamentous undifferentiated hyphae up to 4-9 $\mu \mathrm{m}$ wide, yellowish brown, slightly thick-walled; inflated cells scattered, clavate to subglobose 18-20 × 12-25 $\mu \mathrm{m}$, colourless, hyaline or with light yellowish-brown pigments, slightly thick walled. Stipe context longitudinally acrophysalidic; acrophysalides 80-210 × 24-38 $\mu$ m; filamentous hyphae 2-8 $\mu \mathrm{m}$ wide. Clamp connections absent in all tissues.

Material examined - Uttarakhand, Rudraprayag, Baniyakund, 10 August 2014 TM/RPB 10344.

Notes - Amanita avellaneosquamosa belong to section Amedilla. It is characterized by white to cream covered with reddish blond to brownish orange colour universal veil remnants on pileus. In section Amidella, Amanita avellaneosquamosa, is morphologically close to A. rufobrunnescens and $A$. clarisquamosa. However, A. rufobrunnescens differs from A. avellaneosquamosa by its basidiomata that changing reddish or brownish when bruised (Deng et al. 2016). Amanita clarisquamosa differs by its distinctly brownish universal veil remnants on pileus and shorter striations on the pileus (Yang 1997, 2005).

Table 1 Ecology and distribution of Amanita species

\begin{tabular}{|c|c|c|c|}
\hline Name of species & Habitat & Distribution & Altitude (m asl) \\
\hline Amanita concentrica & $\begin{array}{l}\text { On the ground under } \\
\text { Quercus spp., Myrica } \\
\text { esculenta. }\end{array}$ & $\begin{array}{l}\text { Phedkhal, } \\
\text { Khirsu, Adwani, } \\
\text { Lansdown, } \\
\text { Chamoli, Dodaaj }\end{array}$ & $1650-2050$ \\
\hline Amanita flavipes & $\begin{array}{l}\text { On the ground under } \\
\text { Quercus floribunda, Q. } \\
\text { semecarpifolia, } Q \text {. } \\
\text { dilitata Q. } \\
\text { leucotrichophora, Abies } \\
\text { pindrow, Rhododendron } \\
\text { arboreum }\end{array}$ & $\begin{array}{l}\text { Phedkhal, } \\
\text { Chopta- } \\
\text { Baniyakund, } \\
\text { Chamoli, Doda }\end{array}$ & $1450-2650$ \\
\hline Amanita fritillaria & $\begin{array}{l}\text { On the ground under } \\
\text { Quercus } \\
\text { leucotrichophora. } \\
\text { Cupressus torulosa }\end{array}$ & $\begin{array}{l}\text { Phedkhal, } \\
\text { Jakhdhar }\end{array}$ & $1750-1950$ \\
\hline Amanita avellaneosquamosa & $\begin{array}{l}\text { On the ground under } \\
\text { Quercus semecarpifolia, }\end{array}$ & $\begin{array}{l}\text { Chopta- } \\
\text { Baniyakund }\end{array}$ & 2555 \\
\hline
\end{tabular}

\section{Acknowledgements}

The authors are grateful to the Head, Department of Botany \& Microbiology, HNB Garhwal University, (Srinagar) Garhwal for providing all kinds of facilities during the present study. Field assistance by Dr. Priyanka Uniyal and Mr. Aniket Ghosh (HNBGU) is duly acknowledged. Financial assistance obtained from GBPNIHESD Kosi-Katarmal, Almora is also duly acknowledged.

\section{References}

Bas C. 1969 - Morphology and subdivision of Amanita and monograph of its section Lepidella. Persoonia 5: 285-579.

Bhatt RP, Mehmood T, Uniyal P, Singh U et al. 2017 - Six new records of Amanita (Amanitaceae) from Uttarakhand, India. Current Research In Envirnoment and Applied Mycology.7: 161182.

Corner EJH, Bas C. 1962 - The genus Amanita in Singapore and Malaya. Persoonia 2: 241-304. 
Cui YY, Cai Q, Tang LP, Liu LP et al. 2018 - The family Amanitaceae: molecular phylogeny, higher-rank taxonomy and the species in China. Fungal Diversity 91: 5-230.

Das K, Ghosh A, Chakraborty D, Jingwei L et al. 2017 - Fungal Biodiversity Profiles 31-40. Cryptogamie Mycologie 38 (3): 353-406.

Deng WQ, Li TH, Li P, Hosen MI. 2016 - Amanita rufobrunnescens, a new species of Amanita section Amidella from South China. Phytotaxa 243: 147-154.

Earle FS. 1909 - The genera of the North American gill fungi. Bulletin of the New York Botanical Garden 5: 373-451.

Gilbert EJ. 1940 - Amanitaceae. Iconogr. Mycol. (Milan) 27, suppl. (1-3): 1-427.

Hosen, M, Mehmood T, Das K, Kudzma LV et al. 2018. Amanita tullossiana, a new species, and two new records of Amanita section Lepidella from north-western Himalaya, India. MycoKeys 37: 73-92.

Jenkins DT. 1982 - A study of Amanita types IV. Taxa described by G. F. Atkinson. Mycotaxon 14: 237-246.

Kornerup A., Wanscher J. H. (1978) Methuen Handbook of Colours. 3 edn. Eyre Methuen, London.

Mehmood T, Bhatt R, Uniyal P, Singh U et al. 2018a - Morphological and phylogenetic characterization of genus Amanita from Uttarakhand, India: I. Current Research in Environmental \& Applied Mycology 8: 118-134.

Mehmood, T, Raspé O, Bhatt RP, Singh U et al. 2018b - First record of Amanita subparvipantherina (Amanitaceae) from India. - Current Research in Environmental \& Applied Mycology 8(1): 109-117. Doi 10.5943/cream/8/1/10

Mehmood T, Bhatt RP, Chowdhary AK, Singh U et al. 2018c - Taxonomy and ecological notes on Amanita section Phalloideae (Agaricales: Amanitaceae) in western Himalaya, India. ENVIS Bulletin Himalayan Ecology. 25: 144-152.

Mehmood T, Das K, Hosen MI, Bhatt RP et al. 2018d - Two new species of Amanita (Amanitaceae) from North-western Himalaya, India. Phytotaxa. 367 (3): 219-232.

Neville P, Poumarat S. 2004 - Amaniteae: Amanita, Limacella \& Torrendia. Edizioni Candusso, Alassio, $1120 \mathrm{pp}$.

Persoon CH. 1797 - Tentamen dispositionis methodicae fungorum in classes, ordines, genera et familias cum supplemento adjecto. Petrum Philippum Wolf, Germany, 76 pp.

Roze ME. 1876 - Catalogue des Agaricinées observées aux environs de Paris. Bull. Soc. Bot. France 23: 108-115.

Imai S. 1933 - Studies on the Agaricaceae of Japan I. Volvate agarics in Hokkaido. Botanical Magazine. (Tokyo) 47: 423-32.

Singer, R. 1951- The Agaricales (mushrooms) in modern taxonomy. Lilloa 22: 5-832.

Tibpromma S, Hyde KD, Jeewon R, Sajeewa SN et al. 2017 - Fungal diversity notes 491-602: taxonomic and phylogenetic contributions to fungal taxa. Fungal Diversity 83: 1-261.

Tulloss RE, Lindgren JE. 2005 - Amanita aprica - a new toxic species from western North America. Mycotaxon 91: 193-205.

Tulloss, RE, Yang ZL. 2018 - (Mutable text). Studies in the Amanitaceae - Available from http://www.amanitaceae.org. (Accessed December 2018).

Yang ZL. 1997- Die Amanita-Arten von Südwestchina. Bibliotheca Mycologica 170: 1-240.

Yang ZL. 2005 - Flora fungorum sinicorum. Amanitaceae. Science, Beijing 27: 1-258. 